\title{
Amoxycillin and clavulanic acid in the treatment of urinary infection
}

\author{
L G AL ROOMI, A M SUTTON, F COCKBURN, AND T A McALLISTER
}

University Department of Child Health and Department of Bacteriology, Royal Hospital for Sick Children, and Queen Mother's Hospital, Glasgow

SUMmARY The pharmacokinetics and clinical efficacy of amoxycilin combined with clavulanic acid in the treatment of 32 children with urinary tract infection were studied. Twenty one $(80 \%)$ of 26 children with proved urinary tract infection showed a favourable clinical and bacteriological response. Fifteen of these children had amoxycillin resistant organisms and were treated successfully. In 20 children the serum and urine concentrations of amoxycillin and clavulanic acid were measured after the first oral dose.

Bacterial resistance to commonly used antibiotics which have a $\beta$ lactam ring in their structure, such as the penicillins and the cephalosporins, is a considerable problem. Production of $\beta$ lactamases, enzymes that hydrolyse these antibiotics, is one of the major ways in which bacteria acquire resistance. Sensitive organisms may acquire the ability to synthesise these enzymes and thus become resistant by transfer of an extrachromosomal plasmid that specifies $\beta$ lactamase. Another method of acquiring resistance is chromosomal mediation in the bacterial strain. ${ }^{1}$

There are two ways to combat this problemfirstly to produce antibiotics that are more stable to $\beta$ lactamase, such as the new generation penicillins and cephalosporins, and secondly by a more novel method in which a $\beta$ lactamase inhibitor is added to standard antibiotics. ${ }^{2}$ One of these inhibitor compounds is clavulanic acid, $Z$ - $(2 R, 5 R)-3-$ (hydroxyethylidene) - 7 - oxo - 4 -oxa - 1 - azabicyclo $(3,2,0)$ heptane-2-carboxylic acid, a naturally occurring $\beta$ lactam product of Streptomyces clavuligerus. This is a potent inhibitor of bacterial $\beta$ lactamases, although it has very little intrinsic antibacterial activity. ${ }^{3}$ Microbiological, pharmacological, and clinical studies have shown that clavulanic acid, in combination with amoxycillin is effective and safe in the treatment of infections caused by amoxycillin resistant bacteria in adults. ${ }^{45}$

In this study the pharmacokinetics and efficacy of Augmentin (Beecham Group), a combination of amoxycillin as the trihydrate and clavulanic acid as the potassium salt, were studied in chidren with urinary tract infections caused by amoxycillin sensitive and amoxycillin resistant organisms.

\section{Materials and methods}

Patients. A total of 32 children with suspected urinary tract infections were studied. There were 20 girls and 12 boys, aged between 1 month and 12 years, with a mean age of $5 \cdot 2$ years. The presenting clinical features were loin pain in 8 , increased frequency of micturition and dysuria in 9 , abdominal pain in 9 , enuresis in three, failure to thrive in three, fever in 9 , vomiting in four, and poor feeding in three. Significant bacterial growth was found in the urine of only 26 children $\left(>10^{5}\right.$ pathogens $/ \mathrm{ml}$ in freshly voided urine, or any bacterial growth from a suprapubic bladder aspiration sample).

Methods. At the first interview parental consent for inclusion in the study was obtained and baseline investigations were carried out. These included urine culture; full blood count; liver function tests; and plasma urea, electrolytes, and creatinine concentrations. Three formulations of amoxycillin/ clavulanic acid were used: paediatric suspensions containing amoxycillin $125 \mathrm{mg}$ and clavulanic acid $31.25 \mathrm{mg}$ in $5 \mathrm{ml}(\mathrm{C} 2)$ and $10 \mathrm{ml}(\mathrm{C} 4)$ respectively (ratio 4:1), and a paediatric dispersible tablet containing amoxycillin $125 \mathrm{mg}$ and clavulanic acid $62.5 \mathrm{mg}$ (ratio 2:1). The dose was calculated according to age and body weight (Table 1), and was given 8 hourly for 7 days to all 32 children.

Pharmacokinetic studies were performed in 20 children. Dispersible tablets were used in 9 patients and 11 patients received the paediatric suspensions, (C2 in 6 patients and $\mathrm{C} 4$ in 5 patients). The first oral dose was given after a 4 to 8 hour fast. Blood 
Table 1 Dosage schedule and preparations of amoxycillin and clavulanic acid

\begin{tabular}{llll}
\hline $\begin{array}{l}\text { Weight } \\
(\mathrm{kg})\end{array}$ & Age range & $\begin{array}{l}\text { Dosage } \\
\text { (tid) }\end{array}$ & $\begin{array}{l}\text { Amoxycillin and } \\
\text { clavulanic acid } \\
\text { formulation }\end{array}$ \\
\hline$<3 \cdot 5$ & $<1 \mathrm{mth}$ & $1.5 \mathrm{ml}$ & $\mathrm{C}^{*}$ \\
$3 \cdot 5-4 \cdot 9$ & $1-3 \mathrm{mths}$ & $2 \cdot 0 \mathrm{ml}$ & $\mathrm{C}^{*}$ \\
$5 \cdot 0-8 \cdot 4$ & $3-9 \mathrm{mths}$ & $2.5 \mathrm{ml}$ & $\mathrm{C}^{*}$ \\
$8 \cdot 5-12 \cdot 4$ & $9 \mathrm{mths}-2$ yrs & $5 \cdot 0 \mathrm{ml}$ & $\mathrm{C} 4^{*}$ \\
$12 \cdot 5-18 \cdot 6$ & $2-5$ yrs & $5.0 \mathrm{ml}$ & $\mathrm{C} 2 \dagger$ \\
$>18 \cdot 6$ & $\geqslant 5$ years & 1 tablet & Dispersible tablets $\ddagger$ \\
\hline
\end{tabular}

*Amoxycillin $125 \mathrm{mg}$ and clavulanic acid $31.75 \mathrm{mg}$ in $10 \mathrm{ml}$.

†Amoxycillin $125 \mathrm{mg}$ and clavulanic acid $31.75 \mathrm{mg}$ in $5 \mathrm{ml}$.

$\ddagger$ Amoxycillin $125 \mathrm{mg}$ and clavulanic acid $62.5 \mathrm{mg}$.

samples were taken at 30 minutes, 60 minutes, and 90 minutes thereafter. Urine was collected in timed samples from 0 to 6 hours. Treatment was continued according to the above schedule.

All children were reviewed at the end of the treatment period when repeat blood and urine samples were obtained. Parents and children were questioned specifically to elicit any possible side effects and to assess the clinical response to treatment.

Laboratory methods. The casual organisms were isolated by inoculating Oxoid Dipslides with freshly voided or bladder aspirated urine and incubating for 18 hours at $37^{\circ} \mathrm{C}$. After subculture for purity they were identified by the API method and tested for antimicrobial sensitivity on DST agar (containing $5 \%$ lysed horse blood) against the following discs: Augmentin $30 \mu \mathrm{g}$, (amoxycillin $20 \mu \mathrm{g}$ and clavulanic acid $10 \mu \mathrm{g}$ ), amoxycillin $25 \mu \mathrm{g}$, gentamicin $10 \mu \mathrm{g}$, tobramycin $10 \mu \mathrm{g}$, neomycin $10 \mu \mathrm{g}$, co-trimoxazole $25 \mu \mathrm{g}$, carbenicillin $25 \mu \mathrm{g}$, colistin $10 \mu \mathrm{g}$, sulphonamide $500 \mu \mathrm{g}$, kanamycin $30 \mu \mathrm{g}$, tetracycline $50 \mu \mathrm{g}$, ampicillin $25 \mu \mathrm{g}$, cephaloridine $30 \mu \mathrm{g}$, cephazolin $30 \mu \mathrm{g}$, cephradine $30 \mu \mathrm{g}$, cephalothin $30 \mu \mathrm{g}$, cephalexin $30 \mu \mathrm{g}$, cefoxitin $30 \mu \mathrm{g}$, cefamandole $30 \mu \mathrm{g}$, and cefuroxime $30 \mu \mathrm{g}$.

Minimum inhibitory concentrations for Augmentin and amoxycillin were measured by a plate dilution method incorporating the antibiotics in DST agar and using a surface inoculum of $10^{5}$ organisms. The results were read after incubation for 18 hours at $37^{\circ} \mathrm{C}$ with the end point as the lowest concentration $(\mathrm{mg} / \mathrm{l})$ with no growth or less than five colonies.

Antimicrobials in serum and urine were assayed by a plate diffusion method using wells cut in agar. For amoxycillin, DST agar was seeded with the Oxford staphylococcus as the test organism and for clavulanic acid a $\beta$ lactamase positive Klebsiella pneumoniae was incorporated in benzylpenicillin
DST agar. Zone sizes were compared with controls after overnight incubation at $37^{\circ} \mathrm{C}$.

\section{Results}

Twenty six children had positive urine cultures. The organisms isolated and their sensitivities are shown in Table 2. Cure, judged by sterile urine and relief from symptoms at the end of the treatment period, was achieved in 21 patients $(80 \%)$. Organisms resistant to amoxycillin were found in 16 patients of whom $(96 \%)$ were treated successfully.

Mean inhibitory concentrations were measured for 13 of the organisms isolated and the value was mean (SD), $17.7(14.4) \mathrm{mg} / \mathrm{l}$ (range $1.5-50 \mathrm{mg} / \mathrm{l})$. In 10 of these isolates where the mean inhibitory concentration was $20 \mathrm{mg} / \mathrm{l}$ or less, a good clinical response was achieved. Two patients had persistent bacterial growth, despite the apparent continuing sensitivity of the Escherichia coli involved. In both of these the mean inhibitory concentration was 40 $\mathrm{mg} / \mathrm{l}$. A further two patients were withdrawn from the study during treatment. The first because the organism, Enterobacter cloacae, although sensitive to ampicillin, was resistant to amoxycillin and clavulanic acid (minimum inhibitory concentration $50 \mathrm{mg} / \mathrm{l})$, the second child because of severe diarrhoea. Side effects noted were vulvitis in three patients, loose stools in two, and severe diarrhoea in one (withdrawn). No biochemical or haematological abnormalities were detected before or after the treatment.

Serum concentrations and urinary excretions for both drugs are shown in Tables 3 and 4 . The peak serum concentrations for both amoxycillin and clavulanic acid occurred between 30 and 90 minutes after the oral administration of the tablets and the paediatric suspension- $\mathrm{C} 2$ tablets, mean (SD); amoxycillin $6 \cdot 8(5 \cdot 3) \mathrm{mg} / \mathrm{l}$, clavulanic acid $3 \cdot 4(3 \cdot 2)$ $\mathrm{mg} / \mathrm{l}$ : C2 suspension mean (SD); amoxycillin 9.7 (7) $\mathrm{mg} / \mathrm{l}$, clavulanic acid $4.4(3.8) \mathrm{mg} / \mathrm{l}$. In those taking $\mathrm{C} 4$ suspension, the serum concentrations were highest at 90 minutes (amoxycillin mean (SD); 7.5

Table 2 Infecting organisms isolated and their sensitivities to amoxycillin alone and to amoxycillin with clavulanic acid

\begin{tabular}{lrll}
\hline $\begin{array}{l}\text { Infecting organism } \\
\text { No of } \\
\text { patients }\end{array}$ & $\begin{array}{l}\text { Resistant to } \\
\text { amoxycillin }\end{array}$ & $\begin{array}{l}\text { Resistant to } \\
\text { amoxycillin and } \\
\text { clavulanic acid }\end{array}$ \\
\hline Escherichia coli & 21 & 15 & 0 \\
Proteus mirabilis & 2 & 0 & 0 \\
Entrobacter cloacae & 1 & 0 & 1 \\
Klebsiella pneumoniae & 1 & 1 & 0 \\
Streptococcus faecalis & 1 & 0 & 0 \\
\hline
\end{tabular}


Table 3 Serum concentrations of amoxycillin and clavulanic acid ( $m g / l)$ in 20 children after a single oral dose of amoxycillin and clavulanic acid

\begin{tabular}{|c|c|c|c|c|}
\hline \multirow{2}{*}{$\begin{array}{l}\text { Treatment } \\
\text { group }\end{array}$} & \multirow[t]{2}{*}{ Formation } & \multicolumn{3}{|l|}{ Time } \\
\hline & & $\begin{array}{l}\text { Concentration at } \\
30 \text { minutes } \\
\text { Mean (SD) (range) }\end{array}$ & $\begin{array}{l}\text { Concentration at } \\
60 \text { minutes } \\
\text { Mean (SD) (range) }\end{array}$ & $\begin{array}{l}\text { Concentration at } \\
90 \text { minutes } \\
\text { Mean (SD) (range) }\end{array}$ \\
\hline $\begin{array}{l}\text { Dispersible tablets } \\
(n=9)\end{array}$ & $\begin{array}{l}\text { Amoxycillin }(125 \mathrm{mg}) \\
\text { Clavulanic acid }(62.50 \mathrm{mg})\end{array}$ & 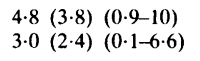 & $\begin{array}{l}6 \cdot 8(5 \cdot 3)(0 \cdot 8-14) \\
3 \cdot 4(3 \cdot 2)(1 \cdot 2-11)\end{array}$ & $\begin{array}{ll}5 \cdot 3 & (3 \cdot 3)(0 \cdot 6-12) \\
2 \cdot 6 & (2 \cdot 1)(0 \cdot 1-6 \cdot 6)\end{array}$ \\
\hline $\begin{array}{l}\text { C2 paediatric suspension } \\
(n=6)\end{array}$ & $\begin{array}{l}\text { Amoxycillin }(125 \mathrm{mg}) \\
\text { Clavulanic acid }(31.75 \mathrm{mg})\end{array}$ & $\begin{array}{l}9.4(8 \cdot 1)(0 \cdot 7-23) \\
2 \cdot 13(1 \cdot 7)(0 \cdot 1-4 \cdot 4)\end{array}$ & $\begin{array}{l}9.7(7 \cdot 0)(0 \cdot 8-23) \\
4.4(3 \cdot 8)(0 \cdot 2-11)\end{array}$ & $\begin{array}{ll}6 \cdot 5 & (4 \cdot 1)(0 \cdot 9-13 \cdot 5) \\
2 \cdot 5 & (2 \cdot 8)(0 \cdot 5-8)\end{array}$ \\
\hline $\begin{array}{l}\text { C4 paediatric suspension } \\
(n=5)\end{array}$ & $\begin{array}{l}\text { Amoxycillin }(125 \mathrm{mg}) \\
\text { Clavulanic acid }(31.75 \mathrm{mg})\end{array}$ & $\begin{array}{ll}2 \cdot 0(1 \cdot 2)(1 \cdot 2-4 \cdot 5) \\
0.9(0 \cdot 7)(0-2 \cdot 0)\end{array}$ & $\begin{array}{l}4.9(1.8)(2.3-6.8) \\
3.1(1.7)(0.4-5.6)\end{array}$ & 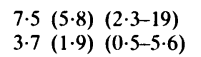 \\
\hline
\end{tabular}

Table 4 Urinary concentrations of amoxycillin and clavulanic acid ( $\mathrm{mg} / \mathrm{l})$ in 20 children after a single oral dose of amoxycillin and clavulanic acid

\begin{tabular}{|c|c|c|c|c|}
\hline \multirow{2}{*}{$\begin{array}{l}\text { Treatment } \\
\text { group }\end{array}$} & \multirow[t]{2}{*}{ Formulation } & \multicolumn{3}{|l|}{ Time } \\
\hline & & $\begin{array}{l}0 \text { to } 2 \text { hours } \\
\text { Mean (SD) (range) }\end{array}$ & $\begin{array}{l}2 \text { to } 4 \text { hours } \\
\text { Mean (SD) (range) }\end{array}$ & $\begin{array}{l}4 \text { to } 6 \text { hours } \\
\text { Mean (SD) (range) }\end{array}$ \\
\hline $\begin{array}{l}\text { Dispersible tablet } \\
(n=9)\end{array}$ & $\begin{array}{l}\text { Amoxycillin }(125 \mathrm{mg}) \\
\text { Clavulanic acid }(62 \cdot 5 \mathrm{mg})\end{array}$ & $\begin{array}{l}202(102)(84-400) \\
61 \cdot 4(34 \cdot 3)(29-120)\end{array}$ & $\begin{array}{l}225(204)(16-800) \\
53(91)(4-400)\end{array}$ & 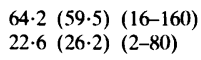 \\
\hline $\begin{array}{l}\text { C2 paediatric suspension } \\
(n=6)\end{array}$ & $\begin{array}{l}\text { Amoxycillin (125 mg) } \\
\text { Clavulanic acid }(31.75 \mathrm{mg})\end{array}$ & $\begin{array}{l}129(70)(70-200) \\
35(48)(2 \cdot 2-120)\end{array}$ & $\begin{array}{l}206(139)(68-500) \\
57 \cdot 3(83)(2 \cdot 7-220)\end{array}$ & $\begin{array}{l}84(29)(37-110) \\
22(16)(0.4-40)\end{array}$ \\
\hline $\begin{array}{l}\text { C4 paediatric suspension } \\
(n=5)\end{array}$ & $\begin{array}{l}\text { Amoxycillin }(125 \mathrm{mg}) \\
\text { Clavulanic acid }((31.75 \mathrm{mg})\end{array}$ & $\begin{array}{l}231(169)(62-400) \\
2 \cdot 7(0 \cdot 75)(2-3 \cdot 5)\end{array}$ & $\begin{array}{l}620(240)(380-860) \\
103(27)(76-130)\end{array}$ & $\begin{array}{l}273(18)(25-600) \\
48 \cdot 6(40)(12-100)\end{array}$ \\
\hline
\end{tabular}

(5.7) $\mathrm{mg} / \mathrm{l}$, clavulanic acid $3.7(1.9) \mathrm{mg} / \mathrm{l})$, but because of the timing of specimens the exact time of peak concentration could not be determined. High urinary concentrations of both drugs were maintained throughout the 0 to 6 hours collection period in all patients. Peak urinary concentrations were reached at between 2 and 4 hours for the three preparations (tablets: amoxycillin $225(204) \mathrm{mg} / \mathrm{l}$, clavulanic acid 53 (91) mg/l; C2 suspension: amoxycillin 205 (139) $\mathrm{mg} / \mathrm{l}$, clavulanic acid $57 \cdot 3(83) \mathrm{mg} / \mathrm{l}$; C4 suspension: amoxycillin $620(24) \mathrm{mg} / \mathrm{l}$, clavulanic acid $103(27) \mathrm{mg} / \mathrm{l})$. The mean urinary excretions from 0 to 6 hours (\% of dose given) were $53 \%$ and $32 \%$ for amoxycillin and clavulanic acid respectively in the tablet group, $14 \%$ and $9 \%$ for $\mathrm{C} 2$, and $37 \%$ and $8 \%$ for $\mathrm{C} 4$ in the suspension group.

\section{Discussion}

The results of the clinical study showed that amoxycillin and clavulanic acid in combination were effective in $80 \%$ of those children with proved urinary tract infections. Bacteriological studies showed that most of these infections were caused by $E$ coli $(81 \%)$, which is similar to the incidence found in other studies of preschool children with urinary tract infections. ${ }^{6}$ In a recent survey of urinary tract infection caused by $E$ coli where 166 different strains of the organism were tested, $84 \%$ were sensitive t co-trimoxazole and only $53.5 \%$ to ampicilliı amoxycillin. $^{7}$

In this study $96 \%$ of the infecting organisms wer sensitive to the combination of amoxycilli clavulanic acid, compared with $36 \%$ sensitivity $t$ ampicillin/amoxycillin alone. Of the 16 patients wit amoxycillin resistant organisms, 15 (96\%) wer treated successfully with this. Ball et al, treatin adult patients with urine infections, achieved a $60^{\circ}$, success rate in patients with amoxycillin sensitiv $E$ coli, and $33 \%$ with amoxycillin resistant $E$ col using the combination (amoxycillin $250 \mathrm{mg}$ an clavulanic acid $125 \mathrm{mg}$ ) 8 hourly. ${ }^{4}$

We found that the dosages used were we tolerated by the children and only one child $\mathrm{d} \epsilon$ veloped diarrhoea after receiving a double dose This incidence of diarrhoea compares favourabl with that reported previously for ampicillin $(8 \mathrm{t}$ $30 \%),{ }^{8}$ and is similar to that found with amoxycilli (2\%). ${ }^{9}$ In one patient, a 3 month old infant, th infecting organism Ent cloacae, was resistant $t$ amoxycillin and clavulanic acid (minimum inhibitor concentration $50 \mathrm{mg} / \mathrm{l}$ ) but sensitive to ampicillin This has been reported previously ${ }^{10}$ and emphasise the importance of using individual sensitivity disc for amoxycillin and ampicillin. ${ }^{11}$ It would seem tha a favourable outcome can be predicted where th 
minimum inhibitory concentration for the combination against the organism is $20 \mathrm{mg} / \mathrm{l}$ or less, but where this exceeded $40 \mathrm{mg} / \mathrm{l}$ the bacteria persisted.

The pharmacokinetic studies showed that all the formulations were well absorbed from the gut. Mean peak serum concentrations occurred between 30 and 90 minutes after administration in the children more than 2 years of age.

Mean apparent peak values for amoxycillin were $6.8 \mu \mathrm{g} / \mathrm{ml}$ for the tablets and $6.5 \mu \mathrm{g} / \mathrm{ml}$ for the suspensions; and for clavulanic acid were $3.8 \mu \mathrm{g} / \mathrm{ml}$ for the tablets and $3.3 \mu \mathrm{g} / \mathrm{ml}$ for the suspensions. These are similar to the therapeutic range reached in adults. ${ }^{12}$ In the age group $0-2$ years, however, the serum concentrations of both drugs continued to increase during the sampling period to 90 minutes. This can be explained by slower absorption, the shorter periods of fasting ( 4 to 6 hours), and delayed urinary excretion. The urinary concentrations of amoxycillin and clavulanic acid combined exceeded the minimum inhibitory concentrations of the sensitive organisms in all cases.

In conclusion, the combination of amoxycillin and clavulanic acid was effective, safe, and well tolerated in all the age groups studied. Good therapeutic concentrations in serum and urine were achieved in the children over the age of 5 years, using a dose of amoxycillin $125 \mathrm{mg}$ and clavulanic acid $62.5 \mathrm{mg}$ (ratio 2:2).

Because of uncertainty about the metabolism of clavulanate by the immature kidney, the younger children in this study were given the combination of amoxycillin and clavulanic acid in the ratio of $4: 1$. The results obtained indicate, however, that a ratio of 2:1 would be satisfactory in children of all ages.

We thank the physicians and surgeons of the Royal Hospital for Sick Children and the Queen Mother's Hospital, Glasgow, for allowing us to study patients under their care. We also thank the nursing staff for their assistance, Miss Jean Hyslop for preparing the graphics, Miss Norma Stirling for typing the manuscript, and the Beecham Group for supplying the formulations of Augmentin.

\section{References}

${ }^{1}$ Sykes RB, Matthew $M$. The $\beta$-lactamases of gram-negative bacteria and their role in resistance to $\beta$-lactam antibiotics. $J$ Antimicrob Chemother 1976;2:115-57.

2 Anonymous. $\beta$ lactam inhibitors-a noval appraoch (editorial). Lancet 1979;ii:565-6.

${ }^{3}$ Reading C, Cole M. Clavulanic acid, A $\beta$-lactamase inhibiting $\beta$ lactam from streptomyces clavuligerus. Antimicrob Agents Chemother 1977;2:852-7.

${ }^{4}$ Ball AP, Geddes AM, Davey PG, Farrell ID, Brookes GR. Clavulanic acid and amoxycillin a clinical, bacteriological and pharmacological study. Lancet 1980;ii:620-3.

5 Fast MV, Nsanze H, D'Costa LJ, et al. Treatment of chancroid by clavulanic acid with amoxycillin in patients with $\beta$-lactamase positive haemophilus ducreyi infection. Lancet 1982;ii:509-11.

6 Bootman R, Laidlaw M, Richards IDG. Prevalence of urinary tract infection in children of preschool age. Arch Dis Child 1974;49:917-22.

${ }^{7}$ McAllister TA. Penicillins in perspective. Scott Med J 1982;27(Suppl):S39-S47.

${ }^{8}$ Bass JW, Crowley DM, Steele RW, Young FSH, Harden LB. Adverse effects of orally administered ampicillin. $J$ Pediatr 1973;83:106-8.

9 Wise PJ, Neu HC. Experience with amoxicillin: an overall summary of clinical trails in the United States. $J$ Infect Dis 1974;129(Suppl):S266-71.

${ }^{10}$ Crump J, Cansdale S. Enterobacter resistant to amoxycillin/ clavulanate (letter). Lancet 1982;ii:500.

11 Brumfitt W, Hamilton-Miller JMT, Dixson S, Gargan RA. Gooding A. Enterobacter resistant to amoxycillin/clavulanate (letter). Lancet 1982;ii:768-9.

12 Jackson D, Cooper DL, Hardy TL, Langley PF, Stamforth DH, Sutton JA. Pharmacokinetic, toxicological and metabolic studies with augmentin. In: Rolinson GN, Watson A, eds. Angmentin: clavulanate-potentiated amoxycillin. Amsterdam: Excerpta Medica 1980.87-105.

Correspondence to Dr L G Al Roomi, University Department of Child Health, Royal Hospital for Sick Children, Yorkhill, Glasgow G3 8SJ.

Received 22 November 1983 